\title{
Changes in Theatrical Performance and Their Influence on the Interpretation of the Melodramas of Zdeněk Fibich
}

\author{
Věra Šustíková, Marta Hrachovinová
}

When discussing theatrical performance practice for the interpretation of melodramas, we must first of all understand that scenic melodrama has to do with acting, and concert melodrama almost always has to do with the related discipline of art that was called declamation in earlier times and later called recitation. At the beginning of the nineteenth century, epics and even lyric poetry were declaimed on the stage, even though they had not been written for theatrical use. We must acknowledge that acting itself has evolved and has been transformed since the end of the nineteenth century, just as artistic presentation has. ${ }^{1}$

The most significant tradition of Czech declamation in the era of the Czech national movement was on the theatrical stage and in the literary evenings of the Umellecká beseda itself. Among the actors who dedicated themselves to acting and poetry readings were Josef Jiří Kolár, Jakub Seifert, and Otýlie Sklenářová-Malá.

For Kolár, the ideal performance of declamation was primarily characterized by strong accentuation, significant pauses, as well as rising and falling intonation in a unified, soaring flight of pathos. Kolár's declamation was not subordinated to the content, the literal reading, or the phonetic aspects of the text. It affected the audience with an emotional torrent of stormy, rattling, and even screaming sounds. The manner of this school of declamation, which had its model in German theatre, was furiously criticized and ridiculed by Jan Neruda. In the 1860 s, he criticized it for universality, lack of refinement, and artificiality.

\footnotetext{
1 "We can define artistic presentation as a vocal realization of the original text with artistic intentions and goals [...] The performer/artist realizes the model of the text into the form of sound from the whole (and from the perspective of the whole), through its individual parts to the details of the original text. The artistic presentation thus realizes the entire original of the text from the perspective of the fundamental stance of the interpreter (of his expressive point of departure), appropriately with the use of other (extralinguistic) techniques of interpretation.” Daniela Musilová and colleagues, Slovnícek uměleckého prédnesu [Dictionary of Artistic Presentation] (Prague, 1981).
} 
So-called "musical declamation" belongs to the later Romantic representational style performed by Jakub Seifert. His mellow baritone voice was also suitable for opera. He took full advantage of his own experience as a singer, and his performance did not focus directly on the spoken word, but on a refined, magical vibrating sound, whose profound emotional effect remained long afterwards in the listeners' consciousness.

Jan Neruda gave much of the credit for the development of the quality of the performance and liberation from the declamatory manner to Otýlie Sklenářová-Malá, the best interpreter of the poems of her contemporaries in that era. ${ }^{2}$ She had a beautiful, supple alto voice; she did not stoop to mere "musical declamation", but strove to express the intention of the author, and to subordinate her vocal expressive techniques to the content of the spoken words, and to express the genesis of the thoughts she interpreted. She was able to combine passionate performance with meticulous application of every metrical aspect of the verse. On stage, her well-trained voice enabled her to satisfy the requirements for a profound individualization of the dramatic roles, and to actualize character. But this manner of recitation went out of date with the new generation. In Adolf Scherl's essay " $Z$ minulosti našeho uměleckého přednesu” [From the Past of Our Artistic Presentation] prepared for the 1966 publication Slyšet se navzájem [Listen Together], one can read the following: "Sklenářová-Malá's declamatory style, which presents a synthesis of Romantic flights of fancy and Romantic sensibility with a realistic sense for authenticity of type and context-a style that later, more objective generations rejected because of its glorious weight, its operatic quality of pathos-was naturally used to particular advantage in melodrama, which arose at precisely that time as a genre of art typical for its era." ${ }^{3}$

We know that Zdeněk Fibich wrote his Štědrý den [Christmas Eve], his first concert melodrama, for this very interpreter in 1875. The first edition (F. A. Urbánek, 1880) is dedicated to Otýlie Sklenářová-Malá; she delivered its premiere, as well as the premieres of other Fibich concert melodramas-Pomsta květin [The Revenge of the Flowers], Věčnost [Eternity] and Vodnik [The Water Sprite]-always with the composer at the piano. ${ }^{4}$ She was also the first Hippodamia in Smrt Hippodamie, the third part of the Hippodamia cycle.

The question arises as to how Fibich would have wanted the melodramas to sound. Also, how the performance practice evolved, and how it differed from our contemporary interpretation. Since sound recordings did not exist at the time, the available sources are Fibich's autographs and the first printed editions of his melodramas; by examining them, we can discern the composer's concepts as they are encoded in the work itself. We must also keep in mind that Fibich was intimately familiar with the theatrical perform-

2 R. Mayer, A. Heyduk, J. V. Sládek, S. Čech, J. Vrchlický, J. Neruda and, of course, K. J. Erben.

3 Adolf Scherl, "Z minulosti našeho uměleckého přednesu” in: Vladimír Justl (ed.), Slyšet se navzájem (Prague, 1966), p. 283.

4 Pomsta květin and Věčnost had their premieres on 16 October 1881: recitation by Otýlie Sklenářová, piano accompaniment by Zdeněk Fibich. The orchestral version of Vodník was first heard on 11 February 1883: recitation by Otýlie Sklenářová, conducted by A. Čech. The premiere of the version with piano took place on 11 March 1883: recitation by Otýlie Sklenářová, piano accompaniment by Zdeněk Fibich. 
ance practice for declamation of actors who interpretated these parts. Other detailed information can be found in related reviews and criticisms, but these sources are often subjectively tinged.

The surviving primary sources are the autograph orchestral versions of Štědrý den and Vodník and copies of the piano versions. ${ }^{5}$ Erben's text is not inscribed in Fibich's hand, but in the rather similar hand of Betty Fibich in the manuscript scores of the melodramas. When additions and markings in his hand appear, they are written in the same manner as the inscribed text. Since Fibich himself was the first interpreter of the piano part of the melodrama, it is possible to infer that the similarity of the inscribed text was not an obstacle for the interpreter, and that the markings may have arisen from quite precise spoken corrections made while the works were played.

The text is inscribed in the first printed edition by F. A. Urbánek in a similar manner. ${ }^{6}$ The text of Śtédrý den is placed between the staves of the piano part, and evidently shows an effort to indicate graphically that the recitation should flow naturally, without regard for metric indications. Speeches and musical/motivic passages begin at the same time, but the inner contents of these passages seem to have been placed very freely. (They often occur as a result of making a shift in the text in order to correspond to a musical phrase.) It was thus left to the ability of the interpreters to sense the relationship of words and music. Fibich evidently relied on his own judgment for the unspecified dimensions of the contour of the words; his instinct for synchronizing the recited poem with the musical form; his ability to present speech intonation in sound and its frequent shifts to instrumental music (using tune-like techniques as the basis of stylized poetic utterance) provide sufficient indications for the musically knowledgeable reciter. Dynamics are indicated only in rough outlines, and sporadically appear in agogic markings and phrasings.

The factors of music and text are worked through in much more detail in the melodrama Vodnik. The text is placed over the staves, explicitly where the composer requested, in such a way that recitation and accompaniment would fall precisely into a unified organic whole, that the stressed words of the poem would occur on the appropriate beats. The appearance of the melodrama score does not indicate whether there could have been technical difficulties in interpretation. The metro-rhythmic aspect of the relationship of words and music is given with compositional logic. But we can only conjecture how the recitation actually sounded. Fibich was a master of declamation in the Czech language and had a clear concept of the sound of the spoken words, yet he understandably worked on the basis of duration.

The requirements of the critics of that era were documented by Karel Scheinpflug in 1899:7 "It is necessary to exercise the voice [...] of the reciter, so that it is softened and

5 These materials are kept in the České muzeum hudby [Czech Museum of Music] under the signatures S 80/106, S 80/107, S 80/108, and S 80/109.

6 The first edition of the piano version of Štédrý den is U 17, undated [1880], and of Vodník. U 122, undated [1883].

7 Karel Scheinpflug, "Recitátor”, Rozhledy, 8 (1899), p. 23. 
strengthened, so that it will acquire luster and depth, range and shadings, so that it can be taught to melt in tears, roar wrathfully, ring with a smile, hiss with derision, stiffen with amazement, so that it can become imbued with a strong agility as well as submissiveness, to be the instrument of every vibration of feeling and every outburst of mood."

Fibich reinforced the artistic strength of the Národní divadlo for most of his concert melodramas with Otýlie Sklenářová-Malá, whose performance style was already showing elements of realism. ${ }^{8}$ A few years later, he chose Josef Šmaha for the orchestral performance of Hakon, his best concert melodrama. ${ }^{9}$ Šmaha has been credited with upholding realism during his lifelong career as actor and director. We could thus infer that Fibich preferred a somewhat unostentatious style of recitation, which sought to interpret the content-while cooperating as closely with the music as possible-over the declamatory pathos perpetuated in that era by many actors from the school of the Prozatímní divadlo [Provisional Theatre].$^{10}$ That, of course, does not mean that it actually was a less spectacular style, as we understand it today. At the time, the concept of ideal melodrama performance practice was that the actor must adapt to the musical current with his declamation, speaking in related harmonic tones. This concept was also required for Fibich's setting of the cycle Hippodamia, whose performances from 1889 to 1891 evoked strong interest among critics.

Josef Bohuslav Foerster made the following public appeal for continuation in an essay about Hippodamia published in Národní listy [National News] in 1890:11 "And what do you seek from singers for performance: good declamation, good actors; these will be indispensably necessary for the music drama!" In the same breath, Foerster praised the performances of Marie Bittnerová as Hippodamia, Jakub Seifert as Pelops, Josef Šmaha in the role of Oinomaos and Jiří Bittner as Myrtillos. He admired Fibich's success in judging the speech contour performance for such differing characters and situations. ${ }^{12}$

8 "Otýlie Sklenářová [continued performing] to the end of her life with noble bearing, a broad epic line and a contour with extensive range [...] her era was romantic, heroic; her era required a queen." (Růžena Nasková, Jak šel život [How Life Went] /Praha 1960/, p. 20).

9 The premiere of the melodrama Hakon took place on 11 March 1888. Josef Šmaha recited under the baton of Adolf Čech. Šmaha was an exceptionally versatile interpreter; he was active in the theatre, operettas and operas, and he directed opera performances; from 1892 to 1894 he taught acting in the dramatic school of the Narodní divadlo, and he had a private school for young opera singers from 1902 to 1904.

10 The question remains as to why the piano version of Hakon was premiered by the above-mentioned Jakub Seifert.

11 Národní listy, 30 (21, 22, and 23 February 1890), Nos. 51, 52, 53.

12 "Every man has a different tempo of speech, which usually corresponds to his character. Let us now consider the natural allegro of Mr. Bittner, or the moderato of Mr. Seifert, with the andante of Mr. Řanda. And thus the changes in these tempi by an individual during scenes of tenderness, peace, seriousness, agitation! For all of these possibilities, you require from the musician an integrity and coherence of the musical part of the melodrama (Ibid.)." 
One could write an independent book about the interpretation of Hippodamia. Here, it is enough to say that the choice of interpreters does not give us enough evidence to reach a conclusion, for we do not know to what extent Fibich could personally choose the actors. It is also clear that compromises had to be made for such massive theatrical content. That is why it is not surprising that the above-mentioned Jakub Seifert appears in a title role, although the "unmusical actor", according to the highly esteemed Eduard Vojan, ${ }^{13}$ "was always given lesser and peripheral roles-he was the herald in Námluvy Pelopovy [The Courtship of Pelops] and the leader of the chorus in Smír Tantaliv [The Atonement of Tantalus]".

Since Fibich's time, our theatrical era has passed from psychological realism through impressionism to expressionism; through depictions of everyday life to materialism and the silencing of today's dramatic performance practice. Each of these trends has manifested itself directly in artistic presentation and influenced the form of melodrama.

Realism weaned the actor from sonorous tirades, declamatory pathos, and large theatrical gesture. Realism also persisted to a marked degree. The impressionist director Kvapil attained effects of melodic intonation of speech-with that particular singing contour of speech which younger Czech actors have inherited from Hana Kvapilová, as long as it did not prevail over the influence of the directors of the Hilar school.

The application of the expressionistic school of K. H. Hilar to Fibich's melodramas was a step to the side, as is documented by the stylized, metric speech of Eduard Kohout which fully revived Hilar's stage direction in Hippodamia. Hilar deliberately gave independence to stylization in sound, and came into conflict with the expressive semantic quality of the word. Here, expressivity in sound was transformed to a flowery decoration in sound.

For later developments, the greater part of the surviving sources understandably have to do with scenic productions of Hippodamia, whose unexpected turns of interpretation led to two important extremes. The first of these occurred during the era of Kovarovic, who refused to participate in the new production of the trilogy. Jaroslav Kvapil decided to produce the work without music to demonstrate that its pivotal significance was in Vrchlický's libretto, and that Fibich's music was actually only an accompaniment. This 1913 attempt ended in a fiasco. Since then, comments about the work have gradually coalesced to the second extreme position: to perform Hippodamia as a spoken opera so that the orchestra has an entirely decisive function, subordinate to the spoken part. This effort came to a climax in 1932 as Ostrčil refused to let the theatre participate in a new

13 According to Jindřich Honzl, Eduard Vojan led the vocal utterance in a new manner-in rhythm and dynamic level of words, in articulation and particularly in giving attention to the Czech consonants. He added accentuation, intensity and expressivity of certain elements of sound that he worked through to unusual resonance (chiefly this had to do with the sound of the letter $r$ ): for the melodic musical expressiveness of words (strength, resonance, color) they have the expressiveness of vowels; for the actual expressiveness in the sound of Czech words they chiefly have the significance of vowels. Vojan created an actual new formation of sound. "Vojan's words seemed to be overburdened with vocal obstacles; every word demanded its own particular and personal energy for its pronunciation." (Jindřich Honzl, "Sláva a bída divadel" [The Glory and Destitution of Theatres], České divadlo, $1 / 1937 /$, manuscript written in 1936, new edition [Prague, 1979], p. 107). 
production. Hence the production went to Ferdinand Pujman, who was the operatic stage director, and the singers of the Národní divadlo were occupied with Hippodamia. On the whole, the critical reception along with Zdeněk Nejedlý enthusiastically welcomed this production. ${ }^{14}$

Pujman's conviction that it was necessary to modify the connection of syncretic and recited word with the norms of music led to a new edition of Fibich's concert melodramas on Erben ballads in 1942, and the so-called 1946 critical edition by Ferdinand Pujman and Jan Hanuš, in which the text is analyzed in relation to the music according to Pujman's precise rules. The words are rhythmically placed in groups of two, three, and four, divided precisely with frequent musical pauses and precisely assigned into beats. Pujman chose polyrhythmic solutions for some passages; for example, he would stipulate a recitation in 4/4 meter with musical accompaniment in 3/4 meter. This approach visibly supported the author's intention for natural spoken performance, and entirely restored the fundamental characteristic of the melodrama. However, it is entirely unrealizable for the actors. Pujman evidently went too far. Nevertheless, his effort brought about something positive: he established the relationship between the verses and the characteristic motives in the music, and divided the verses to correspond to the musical phrases.

However, melodrama slipped away from the concert repertory and the awareness of the public and critics after World War II. Hippodamia became "a responsibility for the anniversary of the composer" in the Národni divadlo in 1950, 1960, and belatedly from 1975 to 1978 . At least the work was heard more frequently in performance. Two exceptional Supraphon projects around 1980 must be mentioned here: the appearance of studio recordings of the entire Hippodamia cycle, and the complete six-part Česky melodram [Czech Melodrama], which also contains the piano versions of all six concert melodramas by Zdeněk Fibich. Today, it is one of the few performance documents for study of melodrama in the Czech Republic. ${ }^{15}$

As we listen to the available recordings and compare the performances of artists, Václav Voska comes to the fore; he was a superb reciter who succeeded in fusing the requirements for artistic presentation with a complete naturalness and authenticity of expression. His speech was absolutely perfect, even with respect to pronunciation, unlike the speech of many other admired and accomplished personalities of yesteryear and today. ${ }^{16}$ Today, the performances of Oinomaos by Rudolf Hrušínský and Myrtillos by Josef Vinklár provide models for giving theatrical shape to Hippodamia. For both Hrušínský and Vinklár everything that has been said above applies in full measure; they succeeded in depicting their dramatic roles in perfect correspondence with their musical characters.

14 Reviews of the 1932 production of Hippodamia at the Národní divadlo. The role of Pelops was played by Otakar Mařák, Hippodamia by Božena Kozlíková, and Myrtillos by Stanislav Muž.

15 Producer and director Lubomír Poživil deserves credit for this effort. One must also mention his related two-part complete Světový melodram [International Melodrama].

16 In this group let us particularly mention the Moravian dialect of Karel Höger, especially his softened letter $\mathrm{i}$. 
The Czech language itself has also undergone a great evolution over the years, which has lessened the difference between the literary and spoken language. The evolution of recitation has led to longer duration in the outer aspect of technical speech (that is, the flexible, supple, and carrying voice, precise and clear pronunciation, agreement with the form and style of the original text), and also to greater attention to the so-called inner technique of speech, the cumulative, concrete inner concept, so that the discourse will be as authentic and natural as possible.

Modern poetics in harmony with our lifestyle rejects pathos and recitation as well. This process always continues. Young reciters in particular avoid pathos; in their effort to attain interpretative effect, they heighten the effect of expressive emotion in speech with interpretive techniques bordering on theatrical action, but they remain very close to reality, authenticity and truth (rather than everyday life) in words of action. A variety of stylizations are evaluated with respect to the personality of the interpreter and the requirements of the director. The new media of radio and television, which have required interpretations with very delicate nuances in the expressive techniques of $\operatorname{speech}^{17}$ and mimicry, were undoubtedly also beneficial for the evolution of artistic presentation practice.

It is clear that the requirements that have been called for since the beginning of time for naturalness and truthfulness, correctness and authenticity of theatrical performance and recitation can-without exception-only be fulfilled by certain artists across the centuries, across diverse artistic styles, schools, fashionable contemporary usages and customs. Requirements differ for modulating the quality of the realization of speech, for the inherent tempo of speech, for the quality and quantity of speech elements, for sensing the rhythm of the Czech language, for using pauses as expressive techniques, and other factors. Nevertheless, audiences, including professional critics, have always preferred those reciters (even if they may not have mastered the best quality of diction, or do not have the most expressive voice) who have been able, first of all, to comprehend the thought and style of the author and his era, have succeeded in acting as an actual intermediary between poet, composer and audience, and have understood how to enrich their performance practice with their own resources.

Today's performances of Fibich's melodramas undoubtedly sound very different from the performances Fibich would have heard. Although their semantic aspect has been preserved, their dramatic aspect evolves along with the concepts of the era about correct utterance. However, our contemporary state of theatrical evolution and artistic performance allows us to respect fully the esthetic requirements of melodrama; that is, to empower its components to work together, to supplement them with new, higher artistic unities, and at the same time fully preserve their specific qualities.

17 Primarily delicate modulations of the range of intonation, with attention to pauses and tempo changes. 


\section{Die Metamorphosen des schauspielerischen Ausdrucks und ihr Einfluss auf die Interpretierung eines Melodrams}

\section{Zusammenfassung}

Wenn wir über den schauspielerischen Ausdruck in Bezug auf die Interpretierung eines Melodrams sprechen, müssen wir uns bewusst werden, dass es sich dabei nicht immer um die Schauspielkunst an sich handelt, sondern meistens um die verwandte künstlerische Disziplin des „künstlerischen Vortrags“ („Rezitation“ bzw. „Deklamation“). Früher wurden die Verse der Dramen genauso wie Gedichte deklamiert, und wie sich die Schauspielkunst gewandelt hat, hat sich auch der künstlerische Vortrag entwickelt und gewandelt. Zdeněk Fibich war ein Meister, was den nicht in Noten ausdrückbaren Tonfall des Wortes und die zeitliche Dauer des interpretierten Textes betrifft, genauso wie die Intonation eines rezitierten Wortes oder Satzes. Seine Fähigkeit einer adäquaten musikalischen Realisierung ist außerordentlich. Das Notenmaterial beinhaltet lediglich eine schriftliche Form des Textes und der Musik, doch wie kommt man zur klanglichen Realisierung? Wie wird sich die heutige Rezitation von der Vorstellung des Komponisten unterscheiden? Die Autorinnen des Beitrags versuchen, aufgrund der Analyse von in der Presse fesgehaltenen Beobachtungen, historischer Tonaufnahmen und vor allem aufgrund ihrer eigenen Erfahrungen mit dem Unterricht des Melodramas diese Fragen nach den Metamorphosen der Rezitation zu beantworten.

Übersetzt von Vlasta Reiterrerová

\section{Proměny hereckého projevu a jejich vliv na interpretaci melodramů Zdeňka Fibicha}

\section{Shrnutí}

Chceme-li mluvit o hereckém projevu ve vztahu $\mathrm{k}$ interpretaci melodramů, musíme si uvědomit, že nejde vždy výslovně o herectví jako takové, ale většinou o příbuznou uměleckou disciplínu, „umělecký přednes“ (dříve „deklamace“, „recitace“). Verše jevištních dramat se dříve deklamovaly stejně jako básně a spolu s tím, jak se proměňovalo herectví, vyvíjel se a proměňoval i umělecký přednes. Zdeněk Fibich byl mistrem v odhadu neoznačitelné míry slovního spádu a časové realizace interpretovaného slova, stejně jako melodického průběhu recitovaného slova a věty. Jeho schopnost adekvátní hudební realizace je zcela mimořádná. Notový materiál uchovává pouze psanou podobu slova a hudby, ale jak je to se zvukovou realizací? Jak se liší dnešní recitace Fibichových melodramů od autorovy vlastní představy? Na tuto otázku se pokoušejí autorky prŕspěvku odpovědět na základě analýzy poznámek v tisku o proměnách recita- 
ce, dochovaných zvukových nahrávek z pozdější doby a především na základě vlastních zkušeností s výukou melodramu.

\section{Keywords}

Melodrama; history of interpretation. 